\title{
ESTARIAM OS HOMENS AVULSOS AO
}

AMOR?

\section{WOULD MEN BE LOOSE TO LOVE?}

HERINGER, V. O AMOR DOS HOMENS AVULSOS. SÃO PAULO: COMPANHIA DAS LETRAS, 2016.

Davidson Maurity Lima Araújo*
Uma vida curta, uma obra concisa, mas não menos marcante. Premiado, Victor Heringer recebeu o prêmio Jabuti por seu livro Glória e foi finalista dos prêmios Rio de Literatura, São Paulo de Literatura e Oceanos por seu livro O amor dos homens avulsos, objeto desta resenha crítica.

O livro, publicado em 2016 pela editora Companhia das Letras, é um objeto cuja capa de cores a marelo vibrante e preto, traz a imagem de bonecos de brinquedo de índios apaches e cowboys sentados em seus cavalos. Um faroeste estático sem os habituais confrontos dos filmes western ou bang-bang, como os conhecemos, tão comuns na cultura norte-americana.
* davidsonmaurity@gmail.com

Mestre em Estudos Literários, concentrado na área de Literaturas Modernas e Contemporâneas da Universidade Federal de Minas Gerais. Membro do grupo de pesquisa Núcleo de Estudos em Letras Sara del Carmen Rojo de la Rosa. Graduado em Letras po DFMG (a) do colivo de teatro Todo

questões relacionadas às identidades de gênero.

Porém, aqui nada de conflitos entre bandidos e moci nhos, com a tiradores perspicazes, rápidos no gatilho, ta qual Clint Eastwood em Três homens e um conflito (1966). Simbólicos, esses bonecos da capa nos trazem essa representação tão difundida e tão presente no nosso imaginário da disputa maniqueísta entre o bem e o mal, entre o virtuoso e o corrupto, mas não é disso que se tra ta o livro. Tratase de homens, mas longe de uma concepção iluminista de sujeitos centrados, dotados de razão, consciência, ação ou de uma identidade inalterável. Sim. Trata-se de homens. Mas longe de uma concepção individualista de sujeito. A subjetividade é um elemento presente no texto e, por isso, 
o a utor nos coloca diante de um sujeito que vai se construindo em relação ao outro e ao mundo público, fora de sua casa. A identidade da personagem, segundo Hall (2000, p. 12), costura um sujeito à estrutura que se apresenta.

Como nos aponta o título, seguiremos numa leitura de 152 páginas sobre a vida de Camilo, um homem cercado de tantos outros: seu pai - médico colaborador da ditadura brasileira -, a migos da escola, da rua e outros homens que mesmo não tão próximos, acabam por fisgar o seu olhar. Seguiremos páginas de uma história familiar através do olhar de um homem e as suas memórias de infância marcadas por um trauma: a morte de Cosme, um menino adotado pelo pai de Camilo. Cosme é seu companheiro, amigo de infância e possivelmente seu primeiro amor.

Antes de começar efetivamente a propor uma discussão sobre o texto, é preciso destacar algo que cha ma muita atenção, logo no primeiro conta to com a obra: os paratextos, elementos verbais e visuais que apresentam, junto à leitura dos textos, informações de teor pragmático, semântico, estético e literá rio. O livro está repleto deles e conduzem o nosso olhar, nossa compreensão e nosso imaginário sobre o texto.

Encontraremos pelas páginas afora fotos do acervo do autor ou de outros artistas e, ta mbém, elementos gráficos como pequenos sóis (:,) espalhados ao longo do livro, junto ao texto. Veremos recortes de imagens que lembram um boletim escolar, uma espécie de lista de presentes ordinários, uma sequência de 40 tipos físicos que a personagem organiza a partir dos seus colegas de classe, como metonímia dos tipos físicos do mundo. Essa sequência é a abrevia tura do nome dos colegas seguidos dos símbolos de masculino (M.H. §̊) e feminino (R.S.X ९). Para além desses elementos e da capa, que, para mim, é dotada de muitos significados, uma informação na segunda orelha do volume sugere uma reflexão sobre todo o livro: Victor Heringer está morto (1988-2018). Não como figura de linguagem e, sim, literalmente. Estamos diante de uma obra cujo autor, mesmo tão jovem, já não está entre nós. Se procurarmos notícias sobre sua morte, não encontraremos a causa, e isso já nos diz a causa da morte. Ela é impublicável.

Ao saber dessa informação, retomo logo a imagem dos apaches e cowboys presentes na capa desse livro. Homens que a história e a cultura cinema tográfica dos E.U.A. construíram como seres valentes, incorruptíveis, másculos e nada frágeis. Figuras consideradas balizadoras de um tipo de padrão do que é ser homem. Ao fazer uma leitura sobre determinados personagens masculinos da cultura brasileira, Guacira Lopes Louro, em seu livro Um corpo estranho: ensaios sobre sexualidade e teoria queer, pondera: "Uma matriz 
heterossexual delimita os padrões a serem seguidos e, ao mesmo tempo, paradoxalmente fornece a pauta para as transgressões." (LOURO, 2008, p. 17). Porta nto, tais histórias, seja a do próprio autor, seja a do personagem, quebram esse paradigma sociocultural de masculinidade, de uma heterossexualidade naturalizada e compulsória. Do primeiro temos a trágica morte, aparentemente, não como um exercício de honra, justiça ou poder, como determinados homens insistem em exercer. Mas, possivelmente, como uma redenção. Do segundo, temos na narrativa uma história de vida motivada pela tentativa de compreensão das experiências vividas, das lembranças, da brutalidade mas também da delicadeza, da consciência, bem como da intuição, da objetividade e da subjetividade. Um personagem construído na lida das possibilidades e não sob um regime de fixidez.

O amor dos homens avulsos é uma obra que traz a vida de um homem, à deriva. Trata-se das memórias desse homem ainda menino num subúrbio carioca. E como todo subúrbio, ele vem carregado de uma carência. Está isolado e é um lugar de difícil acesso.

\section{INFORME METEREOLÓGICO}

A temperatura deste romance está sempre acima dos $31^{\circ} \mathrm{C}$. Umidade relativo do ar: jamais abaixo dos 59\%. Ventos: nunca ultrapassam os $6 \mathrm{~km} / \mathrm{h}$, em nenhuma direção. $O$ mar está muito longe deste livro. (HERINGER, 2016, p. 10).

É assim que começa essa história, uma autobiografia ficcional, no quente bairro do Queím, no subúrbio carioca. Um a mbiente quente e úmido onde a sensação de desconforto é grande. Em luga res assim é comum sentir exaustão pelo calor, cãibras, tonturas e pressão baixa. Em lugares assim, a sensação de inadequação é grande. É esse sentimento que temos ao nos depararmos com Camilo, o protagonista desse livro.

Sempre achei que tinha vindo ao mundo não para estar nele, mas para ter estado, ter sido, ter feito. Nasci póstumo. Fui um natimorto nos braços de mamãe, enforcado pelo cordão umbilical, roxo, roxinho; o médico me reviveu com um sopro na boca. Meu primeiro beijo. Por pouco não me livrei do incômodo de ter nascido. Daí em diante, foi a teimosia do sangue o que me manteve vivo. (HERINGER, 2016. p. 24).

É assim que a personagem é colocada no mundo, contando sobre o próprio nascimento. A perspectiva da história é do próprio Camilo, narrada em primeira pessoa, num recorte de tempo de 50 anos atrás, na década de 1970. 
A história de Camilo está intimamente ligada ao bairro em que nasceu e os seus relatos não transcendem esse local. Camilo se lembra dos lugares por onde brincou, do caminho da escola, dos amigos do bairro, das pessoas que morava mali, da casa onde morou. É ali que os conflitos se dão. Os seus, os de sua fa mília, das pessoas próximas.

Ao revisitar sua própria história, Camilo, como qualquer um de nós, retoma sua trajetória de maneira crítica, titubeante, nem sempre precisa. A memória é o traço comum da trama discursiva do "espaço biográfico", como nos fala Coelho (2013, p. 206). A história de $O$ amor dos homens avulsos é a de uma saudade. Tal qual a passionalidade desse sentimento, desse evento, ela é contada pelos rompantes românticos, furiosos, tristes, de insatisfação e de deleite. O que poderia ser uma distração para a leitura essa forma de escrita "imprecisa", torna-se um elemento de aproximação do leitor com a obra. E por mais que a leitura nos dê a impressão de la mpejos de memória, o texto não se constrói de maneira fragmentada, ou por ideias desconexas. A história está organizada em capítulos de tamanhos diferentes, que fazem um movimento de ida e vinda do seu presente conectado aos conflitos de seu passado, numa escrita realista, performática, reflexiva. Essa característica relaciona uma escrita que incorre não só na presença do narrador diante da sociedade, mas também a do próprio autor diante do seu tempo e as discussões em que ele está inserido, demonstrando que não há como pensar a literatura como um fenômeno social isolado.

\section{REFERÊNCIAS}

COELHO, Haydée Ribeiro. Correspondência e outras memórias compartilhadas no "espaço biográfico". In: GONZÁLES, Elena Palmero; COSER, Stelamaris (Org.). Entre traços e rasuras: Intervenções da memória na escrita das Américas. Rio de Janeiro: 7Letras, 2013, p. 205-224.

\section{HALL, Stuart. A identidade cultural na pós-modernidade.}

Tradução Guacira Lopes Louro, Tomaz Tadeu da Silva. 4. ed. Rio de Janeiro: DP\&A, 2000

HERINGER, Victor. $\mathbf{O}$ amor dos homens avulsos. São Paulo: Companhia das Letras, 2016.

LOURO, Guacira. Viajantes pós-modernos. In: LOURO, Guacira. Um corpo estranho: Ensaios sobre sexualidade e teoria queer. Belo Horizonte: Autêntica Editora, 2008, p. 11-25.

Recebido em: 02-12-2019. Aceito em: 26-01-2020 